AJIE - Asian Journal of Innovation and Entrepreneurship

(e-ISSN: 2477-0574; p-ISSN: 2477-3824)

Vol. 02, No. 02, May 2017

\title{
ANALISIS RETURNS TO SCALE PRODUKSI TENUN LURIK DI KECAMATAN CAWAS, KABUPATEN KLATEN
}

\author{
Sahabudin Sidiq ${ }^{1^{*}}$, Andhika Rizky Paradita ${ }^{2 *}$ \\ ${ }^{1}$ Fakultas Ekonomi Universitas Islam Indonesia \\ ${ }^{2}$ Alumni Fakultas Ekonomi Universitas Islam Indonesia \\ *sahabuddin.sidiq@uii.ac.id
}

\begin{abstract}
ABSTRAK
Penelitian ini bertujuan untuk menganalisis returns to scale produksi tenun lurik di Kecamatan Cawas, Kabupaten Klaten. Kecamatan Cawas merupakan sentra penghasil tenun lurik dengan jumlah unit usaha paling banyak di Kabupaten Klaten. Variabel-variabel yang diteliti antara lain tenaga kerja, pengalaman, bahan baku, dan modal awal. Penelitian ini menggunakan model fungsi produksi Cobb-Douglas melalui uji multikolinearitas, uji heteroskedastisitas, uji autokorelasi, uji $F$, uji $t$, dan koefisien determinasi.

Metode pengumpulan data dilakukan dengan metode wawancara, kuesioner, dan dokumentasi dengan jumlah sampel penelitian sebanyak 75 unit usaha. Hasil estimasi menunjukkan faktor tenaga kerja dan bahan baku signifikan pada a=10\%, sedangkan faktor pengalaman dan modal awal tidak signifikan terhadap produksi tenun lurik. Nilai returns to scale sebesar 1,144701 menunjukkan bahwa usaha tenun lurik mengalami increasing returns to scale.
\end{abstract}

Kata kunci : usaha kecil dan menengah, faktor produksi, Cobb-Douglas

\begin{abstract}
The goals of this research to analyze the returns to scale the production of weaving striated in District Cawas, Klaten Regency. Subdistrict Cawas a striated weaving production centers with the most number of business units in the district of Klaten. The variables studied include labor, experience, raw materials, and the initial capital. This study uses a model of Cobb-Douglas production function through multicollinearity test, heteroscedasticity test, autocorrelation test, $F$ test, $t$ test, and the coefficient of determination.

The Methods of data collection conducted by interview, questionnaire, and documentation with the number of samples are 75 business units. The result indicates the factors of labor and raw materials is significant at $a=10 \%$, while the experience factor and the initial capital is not significant to the production of weaving striated. Value returns to scale of 1.144701 indicates that loom striated experiencing increasing returns to scale.
\end{abstract}

Keywords : small and medium enterprises, production factors, Cobb-Douglas

\section{PENDAHULUAN}

Pembangunan ekonomi diarahkan untuk mempercepat pemulihan kondisi perekonomian dan mewujudkan pembangunan berkelanjutan yang berdasarkan ekonomi kerakyatan. Misi pembangunan ekonomi nasional adalah berusaha untuk mengatasi krisis ekonomi 
beserta dampak yang ditimbulkan, mengatasi kesenjangan ekonomi antar pelaku antara pusat dan daerah, serta pemerataan pendapatan, dan masalah ekonomi lainnya. Pembangunan ekonomi harus diwujudkan dalam rangka untuk mencapai tujuan pembangunan nasional, sehingga mampu mewujudkan masyarakat yang sejahtera, merata material dan spiritual berdasarkan Pancasila serta UUD 1945 dalam wadah Negara Kesatuan Republik Indonesia yang merdeka, sejahtera, adil, dan makmur.

Dalam pembangunan ekonomi nasional, salah satu sektor yang memiliki peran strategis adalah sektor Usaha Kecil dan Menengah atau biasa disingkat menjadi UKM. UKM memiliki peran strategis dalam pembangunan ekonomi karena selain berperan dalam pertumbuhan ekonomi dan penyerapan tenaga kerja juga berperan dalam pendistribusian hasil-hasil pembangunan. Sulistyastuti (2004) menyatakan ada empat alasan yang menjelaskan peran strategis UKM di Indonesia. Pertama, UKM tidak memerlukan modal yang besar sebagaimana perusahaan besar sehingga pembentukan usaha ini tidak sesulit perusahaan besar. Kedua, tenaga kerja yang diperlukan oleh industri kecil tidak menuntut pendidikan formal yang tinggi. Sebagian besar tenaga kerja yang diperlukan oleh industri kecil didasarkan atas pengalaman (learning by doing) yang terkait dengan faktor historis (path dependence). Ketiga, sebagian besar industri kecil berlokasi di pedesaan dan tidak memerlukan infrastruktur sebagaimana perusahaan besar. Keempat, industri kecil telah terbukti memiliki ketahanan yang kuat (strong survival) ketika Indonesia dilanda krisis ekonomi.

Sektor UKM memiliki ketahanan yang kuat dalam menghadapi krisis, hal tersebut terbukti pada saat krisis ekonomi yang melanda Indonesia beberapa waktu yang lalu. Ketika banyak usaha besar yang mengalami stagnasi atau bahkan berhenti beraktifitas, sektor UKM lebih mampu bertahan dalam menghadapi krisis tersebut. Berdasarkan tabel 1.1 dapat dilihat perkembangan UKM di Indonesia, bahwa nilai produksi UKM di Indonesia terus mengalami peningkatan pada setiap tahun. Tabel 1.1 di bawah ini menunjukkan perkembangan usaha kecil, menengah dan besar di Indonesia antara tahun 2010-2013.

Tabel 1.

Perkembangan Usaha Kecil, Menengah dan Besar di Indonesia Menurut PDB Atas Harga Dasar Konstan 2000 Tahun 2010-2013

\begin{tabular}{|c|l|c|c|c|c|}
\hline \multirow{2}{*}{ No } & \multirow{2}{*}{ Indikator } & \multicolumn{4}{|c|}{ Jumlah Nilai Produksi (Rp Milyar) } \\
\cline { 3 - 6 } & & 2010 & 2011 & 2012 & 2013 \\
\hline 1 & Usaha Kecil & $239.111,4$ & $261.315,8$ & $294.260,7$ & $342.579,19$ \\
\hline 2 & Usaha Menengah & $324.390,2$ & $346.781,4$ & $366.373,9$ & $386.535,07$ \\
\hline 3 & Usaha Besar & $935.375,2$ & $1.007 .784,0$ & $1.073 .660,1$ & $1.133 .396,05$ \\
\hline
\end{tabular}

Sumber: Kementrian Koperasi dan Usaha Kecil dan Menengah, 2013
Dalam rangka pembangunan ekonomi yang bertujuan meningkatkan kesejahteraan masyarakat, maka
pembangunan ekonomi lokal sesuai potensi daerah masing-masing menjadi sangat penting. Sejalan dengan era 
desentralisasi, otonomi daerah memberikan kewenangan bagi setiap daerah untuk merencanakan sendiri pembangunan di daerahnya dengan dukungan sumber daya lokal. Hal ini menjadikan posisi UKM sangat penting untuk mewujudkan pembangunan perekonomian dan pemberdayaan masyarakat.

Di Provinsi Jawa Tengah, UKM tersebar pada banyak sektor usaha, antara lain pertanian, industri, perdagangan, pertambangan dan sebagainya. Jawa Tengah memiliki sumber daya yang beraneka ragam dengan jumlah penduduk mencapai 33 juta jiwa (BPS, 2014). Kondisi demikian menjadikan iklim usaha di wilayah Jawa Tengah khususnya UKM memiliki potensi yang besar untuk dapat dikembangkan.

Klaten adalah salah satu kabupaten di Provinsi Jawa Tengah yang memajukan pembangunan perekonomian dengan mengembangkan industri Usaha Kecil dan Menengah. Seperti yang terdapat pada tabel di bawah ini yang menunjukkan perkembangan banyaknya perusahaan industri di Kabupaten Klaten antara tahun 2010-2013.

Tabel 2.

Banyaknya Perusahaan Industri di Kabupaten Klaten Tahun 2010-2013

\begin{tabular}{|c|c|c|c|}
\hline Tahun & Industri Besar/Menengah & Industri Kecil & Jumlah \\
\hline 2010 & 126 & 32.798 & 32.924 \\
\hline 2011 & 126 & 33.937 & 34.063 \\
\hline 2012 & 130 & 33.951 & 34.081 \\
\hline 2013 & 131 & 34.121 & 34.252 \\
\hline
\end{tabular}

Sumber: Badan Pusat Statistik Kabupaten Klaten, 2013

Kabupaten Klaten yang terletak diantara Provinsi Daerah Istimewa Yogyakarta dan kota Solo, yang termasuk dalam Kasunanan Surakarta, menyebabkan kebudayaan yang ada dan berkembang secara umum masih mengikuti kebudayaan-kebudayaan daerah di sekitarnya. Kebudayaan tersebut antara lain, tari-tarian, upacara adat, baju khas daerah, dan kain tradisional, salah satunya yaitu kain tenun lurik. Tumbuh dan berkembang di daerah Jawa, kain tenun lurik menjadi kain khas untuk beberapa daerah di Jawa. Meskipun menjadi kain khas beberapa daerah, namun kain lurik memiliki perbedaan-perbedaan antara lain pada motif dan kualitas kainnya (Wardani, 2011). Seperti halnya kain batik yang menjadi kain khas daerah Yogyakarta,
Solo, dan Pekalongan, atau kain tenun troso yang merupakan kain khas Jepara, Klaten juga memiliki potensi tinggi di bidang ekonomi industri kain tenun tradisional khususnya kain tenun lurik.

Industri tenun lurik di Klaten pada umumnya dikelola oleh UKM. Dalam proses produksi tenun lurik, peralatan yang digunakan adalah alat tenun tradisional yang biasa disebut ATBM atau Alat Tenun Bukan Mesin. Sentra industri tenun lurik ATBM di Kabupaten Klaten tersebar di 6 kecamatan, antara lain di Kecamatan Bayat, Kecamatan Cawas, Kecamatan Trucuk, Kecamatan Pedan, Kecamatan Karangdowo, Kecamatan Polanharjo. Adapun tabel di bawah ini menunjukkan banyaknya unit usaha serta jumlah tenaga 
Tabel 3.

Banyaknya Unit Usaha dan Tenaga Kerja Pada Industri Tenun Lurik ATBM di Klaten Menurut Kecamatan Tahun 2014

\begin{tabular}{|c|l|c|c|}
\hline No & \multicolumn{1}{|c|}{ Kecamatan } & Unit Usaha & Tenaga Kerja \\
\hline 1 & Bayat & 253 & 760 \\
\hline 2 & Cawas & 663 & 1364 \\
\hline 3 & Trucuk & 55 & 158 \\
\hline 4 & Pedan & 38 & 174 \\
\hline 5 & Karangdowo & 31 & 65 \\
\hline 6 & Polanharjo & 12 & 240 \\
\hline & Jumlah & 1052 & 2761 \\
\hline
\end{tabular}

Sumber: Disperindagkop dan UMKM Kabupaten Klaten, 2014

Kecamatan Cawas merupakan salah satu sentra penghasil tenun lurik di Kabupaten Klaten. Berdasarkan tabel 1.3 di atas menunjukkan bahwa Kecamatan Cawas merupakan sentra penghasil tenun lurik dengan jumlah unit usaha paling banyak dibandingkan dengan kecamatan lain di Kabupaten Klaten. Jumlah total unit usaha tenun lurik di Kecamatan Cawas tercatat sebanyak 663 unit usaha. Jumlah tersebut merupakan $63,02 \%$ dari total unit usaha tenun lurik di Kabupaten Klaten yaitu berjumlah 1052 unit usaha. Untuk jumlah tenaga kerja yang bekerja pada usaha tenun lurik di Kecamatan Cawas berdasarkan tabel di atas adalah sebanyak 1364 orang atau $49,40 \%$ dari jumlah total tenaga kerja yang bekerja pada usaha tenun lurik di Kabupaten Klaten.

Industri tenun lurik di Kecamatan Cawas masih tergolong industri rumah tangga, artinya proses produksinya dikerjakan di rumah sendiri yang berskala kecil dan menengah. Pengelolaan manajemen dalam usaha tenun lurik pun masih bersifat sederhana dan belum sepenuhnya ditangani secara profesional. sehingga perkembangannya relatif lamban.
Permasalahan umum yang dialami pelaku usaha tenun antara lain adalah masalah pemasaran produk. Dalam pemasaran hasil produksi masih banyak yang bergantung pada tengkulak atau pedagang yang memesan produk yang dihasilkan. Masih banyak pelaku usaha tenun lurik yang belum memiliki outlet-outlet khusus untuk menjual secara langsung produknya kepada konsumen. Padahal pemasaran ini menjadi faktor paling penting untuk meningkatkan pendapatan.

Untuk menghadapi masalah yang ada dalam usaha tenun lurik, para pelaku usaha tenun lurik di Kecamatan Cawas tergabung dalam satu kelompok, yaitu Cawas Lurik Center yang merupakan wadah bagi para pelaku usaha tenun lurik di Kecamatan Cawas untuk saling bekerjasama mengembangkan usaha tenun lurik di Kecamatan Cawas yang tersebar di 20 desa. Bentuk kerjasama antar pelaku usaha antara lain adalah berupa pembagian jatah produksi terutama jika terdapat pesanan tenun lurik dalam jumlah besar. Selain itu kerjasama antar pelaku usaha adalah dalam penyediaan bahan baku yang 
digunakan pada proses produksi, hingga masalah pemasaran produk.

Lurik adalah karya seni budaya yang merupakan brand image Klaten yang patut dilestarikan keberadaannya dan dikembangkan secara maksimal. Oleh karena itu, pemerintah daerah diharapkan untuk membantu menggali potensi masyarakat untuk mengembangkan industri tenun lurik dalam rangka meningkatkan kesejahteraan masyarakat yang memberikan multiplier effect terhadap pertumbuhan perekonomian daerah serta meningkatkan pendapatan asli daerah.

Dalam melakukan kegiatan produksi agar dapat memaksimalkan hasil produksi dan keuntungan yang diperoleh, pelaku usaha tenun lurik harus mampu untuk mengoptimalkan penggunaan faktor-faktor produksi ditengah pengelolaan manajemen yang masih bersifat sederhana. Berdasarkan hal-hal tersebut di atas maka penulis dalam penelitian ini tertarik untuk melakukan penelitian profil dan menganalisis faktor-faktor yang berpengaruh dalam proses produksi pada usaha tenun lurik di Kecamatan Cawas Kabupaten Klaten. Penulis akan memfokuskan penelitian ini pada penggunaan empat faktor produksi antara lain adalah faktor tenaga kerja, pengalaman (lama menggeluti bidang usaha tenun lurik), bahan baku, dan modal awal.

\section{METODE PENELITIAN}

\section{Kajian Pustaka}

Penelitian degan menggunakan fungsi produksi telah banyak dilakukan . Efie Eka Wanty menggunakan analisis fungsi produksi Cobb-Douglas untuk menganalisis faktor produksi batik cap Pekalongan dengan faktor produksi antara lain, tenaga kerja, kain, lilin batik, pewarna, dan tempat. Faktor-faktor yang berpengaruh positif terhadap produksi batik adalah faktor tenaga kerja, diikuti obat pewarna, lilin batik, tempat dan kain. Faktor yang berpengaruh paling besar terhadap produksi batik adalah faktor tenaga kerja. Disimpulkan bahwa hasil produksi batik cap di Pekalongan mengalami increasing returns to scale. Hal ini ditunjukkan dari nilai $1,184>1$. Dengan demikian outputnya dapat diperbesar lagi. Adapun nilai 1,184 adalah merupakan hasil penjumlahan dari nilai konstanta dijumlah dengan $\beta_{1}+\beta_{2}+\beta_{3}+$ $\beta_{4}+\beta_{5}$.

Akhmad Hidayat pada tahun 2013 melakukan penelitian untuk mengetahui bagaimana pengaruh modal, tenaga kerja, dan bahan baku terhadap nilai produksi serta menganalisis tingkat efisiensi baik efisiensi teknis, efisiensi harga, maupun efisiensi ekonomis pada usaha kecil dan menengah batik di Kelurahan Kauman Kota Pekalongan. Variabel dalam penelitian ini adalah modal (X1), tenaga kerja (X2), bahan baku (X3), dan nilai produksi (Y). Data yang dianalisis menggunakan metode analisis deskriptif kuantitatif, analisis regresi linier berganda dan analisis efisiensi. Hasil uji-t modal dan bahan baku mempunyai pengaruh yang positif terhadap nilai produksi batik. Sedangkan variabel tenaga kerja tidak mempunyai pengaruh yang signifikan terhadap nilai produksi batik. Dari hasil penghitungan efisiensi diperoleh nilai efisiensi teknis sebesar 0,8427. Efisiensi harga sebesar 2,3221 dan efisiensi ekonomi sebesar 1,9568 dan nilai returns to scale sebesar 4,525 yang menunjukkan usaha batik berada pada increasing returns to scale. Kesimpulan dari penelitian ini menunjukkan bahwa belum tercapai 
kondisi efisien pada usaha kecil dan menengah batik di Kelurahan Kauman Kota Pekalongan.

Penelitian yang dilakukan Sri Lestariningsih tahun 2006, menganalisis penawaran dan permintaan industri kecil tenun ikat troso di Kecamatan Pecangaan Kabupaten Demak menunjukkan hasil penelitian bahwa di sisi permintaan (Qd) tingkat harga kain tenun $(\mathrm{Px})$ berpengaruh negatif signifikan pada $\alpha=10 \%$ sedangkan tingkat pendapatan konsumen (Tpk) dan harga barang subtitusi (Hbs) berpengaruh positif dan signifikan pada $\alpha=5 \%$. Sedangkan nilai $\mathrm{R}^{2}$-nya sebesar $17,6 \%$ artinya variabel permintaan kain tenun ikat troso dapat dijelaskan oleh variabel harga kain, tingkat pendapatan konsumen dan harga barang subtitusi sebesar 17,6\% sedangkan sisanya $82,4 \%$ diterangkan oleh faktor yang lain. Sedangkan dari sisi penawaran (Qs), variabel harga kain tenun berpengaruh positif dan biaya produksi berpengaruh negatif. Keduanya signifikan pada $\alpha=5 \%$. Nilai $\mathrm{R}^{2}$ nya adalah $38 \%$ sedangkan sisanya $62 \%$ diterangkan oleh variabel lain selain harga dan biaya produksi. Untuk harga keseimbangan yang terjadi antara permintaan dan penawaran adalah Rp 50.151,00 per meter sedangkan nilai outputnya 578 meter.

Yuafni (2012) dalam penelitian skripsi faktor-faktor yang mempengaruhi produksi batik pada industri batik di Kota Jambi, mendeskripsikan seberapa besar modal, tenaga kerja, alat dan bahan mempengaruhi produksi kain batik Jambi. Jenis penelitian yang digunakan adalah korelasional. Jumlah sampel adalah 50 industri, teknik pengambilan sampel menggunakan total sampel, yaitu seluruh populasi dijadikan sampel, dengan teknik pengumpulan data menggunakan angket. Pada signifikansi $\alpha=5 \%$, hasil penelitian menyatakan bahwa modal mempengaruhi produksi batik sebesar 39,8\%, tenaga kerja mempengaruhi produksi batik sebesar $25,6 \%$, alat dan bahan mempengaruhi produksi batik sebesar 50,7\%, dan modal, tenaga kerja, alat dan bahan secara bersamaan mempengaruhi produksi batik sebesar $69,1 \%$.

\section{Landasan Teori}

Dalam Penelitian ini menggunakan teori fungsi produksi yang merupakan hubungan dari input produksi, proses produksi sampai produk yang dihasilkan dari proses produksi. Perusahaan dapat mengubah input menjadi output dengan menggunakan variasi tenaga kerja, bahanbahan produksi, dan juga modal. Sebuah fungsi produksi menunjukan output tertinggi yang dapat diciptakan oleh suatu perusahaan untuk suatu kombinasi tertentu input produksi. Pindyck (2009) memformulasikan fungsi produksi menggunakan dua input yang dirumuskan sebagai berikut:

$$
\mathrm{Q}=\mathrm{F}(\mathrm{K}, \mathrm{L})
$$

Persamaan di atas menghubungkan jumlah output dari jumlah kedua input. Dimana Q merupakan output yang dicapai dalam periode waktu, $\mathrm{K}$ dan $\mathrm{L}$ yaitu modal dan tenaga kerja yang digunakan. Fungsi produksi merupakan hubungan antara input atau faktor produksi yang digunakan dengan kuantitas keluaranya atau output yang dihasilkan. Pada proses produksi, produsen akan mengalami atau menemui hukum the law of diminishing marginal return. Hukum tersebut menyatakan penggunaan input yang meningkat sementara input lainnya dalam keadaan tetap, akan menghasilkan tambahan output, dan yang nantinya akan mengalami penurunan. Hal tersebut dapat dicontohkan, apabila input tenaga kerja 
kecil dan modal dalam keadaan tetap, maka penambahan input tenaga kerja akan menambah hasil output karena pekerja dapat menangani tugas-tugas khusus atau spesialisasi. Tetapi pada akhirnya hukum the law of diminishing return akan berlaku, pekerja yang bertambah terlalu banyak akan mengakibatkan beberapa pekerja menjadi tidak efektif. Penambahan faktor produksi dapat dilihat dalam hubungan kurva sebagai berikut:

\section{Gambar 1}

\section{Kurva Fungsi Produksi}

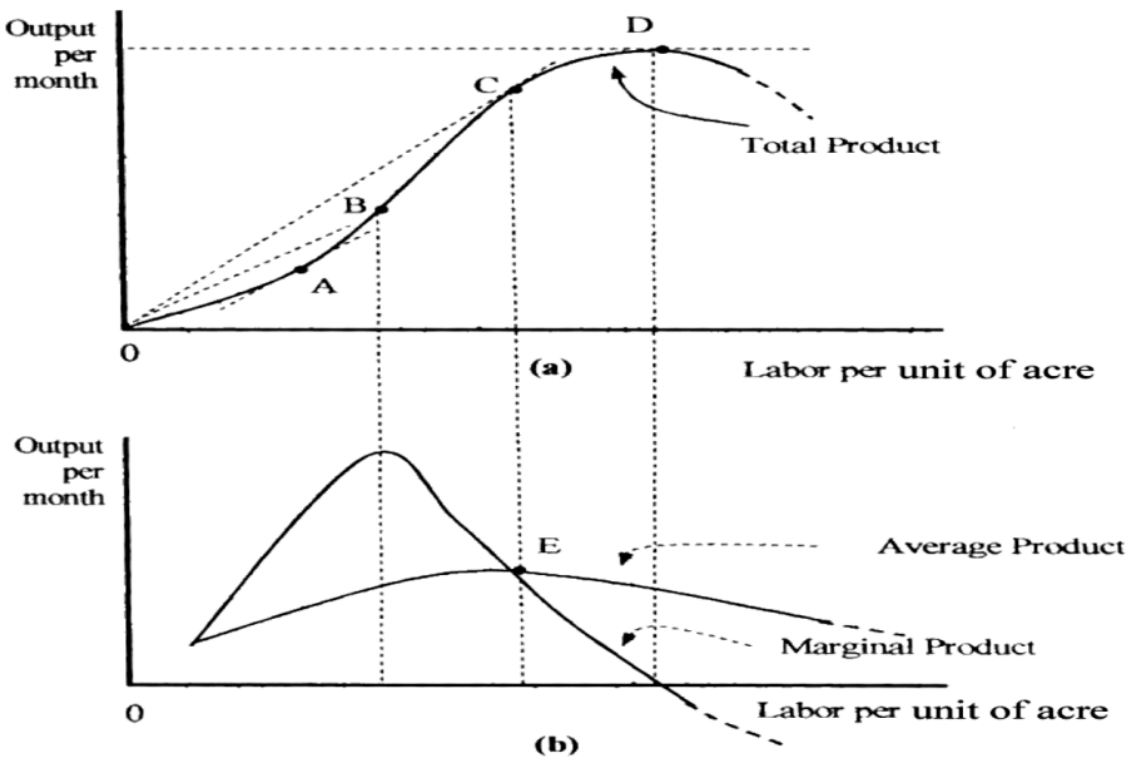

Sumber: Pindyck, 2009

Grafik (a) menunjukan total output yang dicapai dengan input tenaga kerja. output meningkat menuju output maksimum yang digambarkan pada titik D. Setelah mengalami output maksimum penambahan tenaga kerja sudah tidak ekonomis yang digambarkan garis mulai menurun pada kurva (a). Grafik (b) menggambarkan kurva average product dan marginal product. Jika diperhatikan dalam grafik (a) dan (b) marginal product selalu mengikuti total product, apabila output naik maka marginal product akan naik begitu sebaliknya. Marginal product dan average product mempunyai hubungan yang erat, jika marginal product lebih besar dari average product maka average product meningkat. Hal ini berarti penambahan input masih memberikan tambahan output pekerja yang meningkat. Penambahan input akan menyebabkan marginal product melebihi average product. Pada kondisi ini penambahan output mulai menurun. Oleh karena itu daerah ekonomis produksi adalah antara produksi di titik $\mathrm{C}$ dan tingkat produksi di titik D.

Elastisitas merupakan perubahan yang terjadi pada suatu variabel dan menimbulkan dampak perubahan pada variabel yang lain. Pindyck (2009) menyatakan elastisitas menunjukan persentase perubahan yang terjadi pada suatu variabel sebagai reaksi atas setiap satu persen kenaikan pada variabel lain. 
Konsep elastisitas dapat digambarkan dalam persamaan berikut:

$\mathrm{Y}=\mathrm{f}(\mathrm{K})$

Dari persamaan di atas, untuk mengetahui tingkat elastisitas $\mathrm{Y}$ terhadap perubahan $\mathrm{K}$ dapat dinyatakan sebagai berikut:

$$
\varepsilon_{Y, K}=\frac{\partial Y / Y}{\partial K / K}=\frac{\partial Y}{\partial K} \cdot \frac{K}{Y} .
$$

Nilai koefisien elastisitas lebih besar dari satu $(E>1)$ disebut elastis, yaitu persentase perubahan output lebih besar dari persentase perubahan kapital. Jika nilai koefisien elastisitas kurang dari satu $(\mathrm{E}<1)$ dapat dikatakan persentase perubahan output lebih kecil dari persentase perubahan kapital (inelastis).

Fungsi produksi Cobb-Douglas adalah suatu fungsi yang melibatkan dua atau lebih variabel, di mana variabel satu disebut variabel dependen (Y) dan yang lainnya disebut variabel independen $(\mathrm{X})$, penyelesaian hubungan antara $\mathrm{X}$ dan $\mathrm{Y}$ adalah dengan cara regresi, di mana variasi dari $\mathrm{Y}$ akan dipengaruhi variasi dari $\mathrm{X}$ (Soekartawi, 2003). Model fungsi produksi merupakan persamaan yang melibatkan dua atau lebih variabel yang terdiri dari satu variabel tidak bebas $(\mathrm{Y})$ dan variabel bebas (X). Persamaan Cobb-Douglas dituliskan sebagai berikut:

$$
\mathrm{Y}=\mathrm{aX}_{1}{ }^{\mathrm{b} 1}, \mathrm{aX}_{2}{ }^{\mathrm{b} 2}, \mathrm{aX}_{3}{ }^{\mathrm{b} 3}, \ldots \ldots \ldots \ldots . . . \mathrm{aX}_{\mathrm{n}}{ }^{\mathrm{bn}}
$$

Untuk penggunaan ordinary least square $(O L S)$ maka bentuk di atas harus diubah menjadi bentuk linear berganda, dengan menjadikan persamaan log-linier sebagai berikut:

$\log \mathrm{Y}=\log \mathrm{a}+\mathrm{b}_{1} \log \mathrm{X}_{1}+\mathrm{b}_{2} \log \mathrm{X}_{2}+$

$b_{3} \log X_{3}+\ldots \ldots .+b_{n} \log X_{n}+e$

Beberapa hal yang menjadi alasan mengapa fungsi produksi Cobb-Douglas lebih banyak digunakan dalam penelitian. Alasan tersebut adalah:
- Penyelesaian fungsi produksi Cobb-Douglas relatif mudah.

- Hasil pendugaan garis melalui fungsi produksi Cobb-Douglas akan menghasilkan koefisien regresi sekaligus menunjukkan besaran elastisitas.

- Jumlah besaran elastisitas tersebut menunjukkan tingkat returns to scale.

Dalam suatu fungsi produksi, setiap pertambahan input akan menyebabkan terjadinya pertambahan output dalam proporsi tertentu (Pindyck, 2009). Perbandingan antara besarnya pertambahan input dan pertambahan output dijelaskan melalui pengamatan skala atas hasil atau returns to scale. Fungsi utama dari pengamatan tersebut untuk mengetahui seberapa besar output yang dihasilkan apabila semua inputnya ditambah dalam suatu proporsi tertentu. Returns to scale dapat diklasifikasikan menjadi tiga, yaitu:

1. Jika kenaikan yang proporsional dalam semua input sama dengan kenaikan yang proporsional dalam output ( $\varepsilon p=1$ atau $\alpha+\beta=1)$, maka tingkat pengembalian terhadap skala konstan (constant returns to scale).

2. Jika kenaikan yang proporsional dalam output kemungkinan lebih besar daripada kenaikan dalam input ( $\varepsilon p>1$ atau $\alpha+\beta>1$ ), maka tingkat pengembalian terhadap skala meningkat (increasing returns to scale).

3. Jika kenaikan output lebih kecil dari proporsi kenaikan input ( $\varepsilon p<$ 1 atau $\alpha+\beta<1$ ), maka tingkat pengembalian terhadap skala 
menurun (decreasing returns to scale).

\section{Model Regresi}

Metode analisis merupakan alat yang digunakan untuk mengetahui besarnya pengaruh variabel-variabel independen (X) terhadap variabel dependen (Y). Alat analisis yang digunakan dalam penelitian ini adalah fungsi produksi Cobb-Douglas. Model regresi fungsi produksi yang akan digunakan dalam menganalisis produksi tenun lurik di Kecamatan Cawas dalam penelitian ini adalah sebagai berikut:

$$
\begin{gathered}
\log Y=\log \beta_{0}+\beta_{1} \log X_{1}+\beta_{2} \log X_{2}+\beta_{3} \\
\log X_{3}+\beta_{4} \log X_{4}+\mu
\end{gathered}
$$

Tabel 4.

Definisi Variabel Fungsi Produksi Tenun Lurik

\begin{tabular}{|c|l|c|}
\hline Kode & \multicolumn{1}{|c|}{ Definisi } & Satuan \\
\hline $\mathrm{Y}$ & Output/hasil produksi tenun lurik & Meter \\
\hline $\mathrm{X} 1$ & Tenaga kerja yang ikut berproduksi & Orang \\
\hline $\mathrm{X} 2$ & Pengalaman/lama menggeluti sektor tenun lurik & Tahun \\
\hline $\mathrm{X} 3$ & Bahan baku yang digunakan dalam satu bulan & Rupiah \\
\hline $\mathrm{X} 4$ & Modal awal yang digunakan & Rupiah \\
\hline$\beta_{1}-\beta_{5}$ & Koefisien Regresi & \\
\hline
\end{tabular}

Estimasi model dilakukan menggunakan program Eviews 6.0 dengan metode OLS. Estimasi dilakukan dengan merubah variabel-variabelnya terlebih dahulu dengan bentuk logaritma. Bentuk logaritma tersebut dimaksudkan untuk memenuhi fungsi Cobb-Douglas, sehingga koefisien dari variabel independen (X) mencerminkan elastisitasnya.

\section{Jenis dan Metode Pengumpulan Data}

Adapun jenis data yang digunakan dalam penelitian ini adalah data primer dan sekunder. Data primer dalam penelitian diambil secara langsung pada objek penelitian. Pengambilan data diperoleh melalui wawancara langsung dengan pelaku usaha tenun lurik dengan menggunakan daftar pertanyaan yang telah dipersiapkan sebelumnya. Data sekunder merupakan data yang diambil secara tidak langsung. Data sekunder dalam penelitian ini diambil melalui studi kepustakaan, yaitu dari buku-buku literatur, jurnal-jurnal ilmiah, laporan-laporan lembaga yang bersangkutan, serta surat kabar elektronik yang diterbitkan di internet. Untuk melengkapi penelitian ini juga dilengkapi rujukan-rujukan dari penelitian-penelitian terdahulu.

Penelitian ini dilakukan di Kabupaten Klaten pada usaha kecil dan menengah tenun lurik yang berlokasi di Kecamatan Cawas, karena merupakan sentra produksi lurik terbanyak. Sampel yang diteliti adalah sebanyak 75 pelaku usaha tenun lurik. Penarikan sampel dalam penelitian ini dilakukan secara acak (random sampling) di Kecamatan Cawas. Penarikan sampel secara acak sederhana merupakan pengambilan sampel dari populasi secara acak tanpa memperhatikan 
strata yang ada dalam populasi dan setiap anggota populasi memiliki kesempatan yang sama untuk dijadikan sampel (Suryadi, 2009).

\section{HASIL DAN PEMBAHASAN Analisis Deskriptif}

Kecamatan Cawas merupakan salah satu kecamatan dari 26 kecamatan yang ada di kabupaten Klaten, tepatnya terletak $18 \mathrm{~km}$ dari pusat Kabupaten Klaten. Secara geografis Kecamatan Cawas terletak pada posisi $110^{0} .30^{\prime}-110^{0} .45^{\prime}$ Bujur Timur dan $7^{0} .30^{\prime}-7^{0} .45^{\prime}$ Lintang Selatan. Batas-batas wilayah secara administratif antara lain adalah:

1. Sebelah utara : Kecamatan Karangdowo dan Kecamatan Pedan

2. Sebelah selatan : Kabupaten Sukoharjo
3. Sebelah timur : Kabupaten Gunung Kidul (DIY)

4. Sebelah barat : Kecamatan Trucuk dan Kecamatan Bayat

Kecamatan Cawas merupakan salah satu sentra penghasil tenun lurik di Kabupaten Klaten. Berdasarkan data dari Disperindagkop dan UMKM Kabupaten Klaten tahun 2014, jumlah total unit usaha tenun lurik di Kecamatan Cawas adalah sebanyak 663 unit usaha. Jumlah tersebut merupakan $63,02 \%$ dari total unit usaha tenun lurik di Kabupaten Klaten yaitu berjumlah 1052 unit usaha.

Industri Tenun lurik sudah cukup lama berkembang di Kecamatan Cawas. Untuk lebih jelasnya mengenai tahun berdirinya usaha tenun lurik di Kecamatan Cawas dapat dilihat pada tabel berikut:

Tabel 5

Usaha Tenun Lurik di Kecamatan Cawas Dirinci Berdasarkan Tahun Berdiri

\begin{tabular}{|c|c|c|c|}
\hline No. & Tahun Berdiri & Frekuensi & Persentase (\%) \\
\hline 1 & 1981-1990 & 1 & 1,33 \\
\hline 2 & $1991-2000$ & 22 & 29,33 \\
\hline 3 & $2001-2010$ & 49 & 65,33 \\
\hline 4 & $>2010$ & 3 & 4,00 \\
\hline \multicolumn{2}{|r|}{ Jumlah } & 75 & $100 \%$ \\
\hline
\end{tabular}

Sumber: Data Primer Diolah

Dari tabel 4.1 di atas menunjukkan bahwa tahun berdiri usaha tenun lurik di Kecamatan Cawas paling banyak antara tahun 2001-2010 yang jumlahnya mencapai sejumlah 49 unit usaha $(65 \%)$ dan paling sedikit adalah antara tahun 1981-1990 yang hanya berjumlah 1 unit usaha $(1,33 \%)$.

Masyarakat Kecamatan Cawas selain bermata pencaharian dalam bidang pertanian, sebagian besar juga bermata pencaharian dalam bidang usaha tenun lurik. Data dari Disperindagkop dan
UMKM Kabupaten Klaten tahun 2014 mencatat bahwa terdapat sebanyak 1364 orang tenaga kerja yang bekerja dalam bidang usaha tenun lurik di Kecamatan Cawas. Dalam penggunaan tenaga kerja, para pelaku usaha harus memperhatikan berapa banyaknya jumlah tenaga kerja yang dibutuhkan. Hal ini berkaitan dengan besarnya biaya produksi dan pendapatan yang diterima. Untuk lebih jelasnya tabel di bawah ini menunjukkan hasil observasi jumlah penggunaan tenaga kerja oleh pelaku usaha tenun lurik: 
Tabel 6

Jumlah Penggunaan Tenaga Kerja Pada Usaha Tenun Lurik

\begin{tabular}{|c|c|c|c|}
\hline No. & Jumlah Tenaga Kerja & Frekuensi & Persentase $(\%)$ \\
\hline 1 & $1-5$ & 43 & 57,33 \\
\hline 2 & $6-10$ & 26 & 34,67 \\
\hline 3 & $11-15$ & 3 & 4,00 \\
\hline 4 & $16-20$ & 2 & 2,67 \\
\hline 5 & $21-30$ & 1 & 1,33 \\
\hline \multicolumn{2}{|r|}{ Jumlah } & 75 & $100 \%$ \\
\hline
\end{tabular}

Sumber: Data Primer Diolah

Berdasarkan tabel di atas, jumlah penggunaan tenaga kerja yang paling banyak pada usaha tenun lurik adalah antara 1-5 orang tenaga kerja dengan jumlah 43 unit usaha $(57,33 \%)$ dan yang paling sedikit adalah penggunaan tenaga kerja antara 21-30 orang yaitu hanya ada 1 unit usaha $(1,33 \%)$.

Tenaga kerja pada usaha kecil dan menengah tenun lurik di Kecamatan Cawas rata-rata sudah berusia antara 40-50 tahun. Hal ini disebabkan karena tenaga kerja usia muda di Kecamatan Cawas kurang tertarik untuk masuk ke dalam usaha tenun lurik. Mereka lebih memilih untuk bekerja di pabrik-pabrik atau merantau ke daerah lain. Kondisi ini menimbulkan kekhawatiran pada sebagian pelaku usaha tenun lurik karena mereka menjadi kesulitan untuk melakukan regenerasi tenaga kerja sedangkan tenaga kerja yang mereka miliki berangsur memasuki usia senja dimana produktivitas mereka akan semakin menurun.

Industri tenun lurik di Kecamatan Cawas masih tergolong industri rumah tangga, artinya proses produksinya dikerjakan di rumah sendiri yang berskala kecil dan menengah. Oleh karena itu, dalam memulai usaha tenun lurik para pelaku usaha bisa memulai mendirikan usaha dengan modal awal yang tidak cukup besar. Meski dengan modal awal yang tidak cukup besar, usaha tenun lurik dapat dikembangkan dengan memanfaatkan keuntungan yang diperoleh untuk kemudian digunakan sebagai modal tambahan untuk membeli peralatan baru serta menambah jumlah bahan baku yang digunakan. Berikut tabel penggunaan modal awal oleh para pelaku usaha tenun lurik:

Tabel 7

Penggunaan Modal Awal Pada Usaha Tenun Lurik

\begin{tabular}{|c|c|c|c|}
\hline No. & Jumlah Modal (Juta Rupiah) & Frekuensi & Persentase (\%) \\
\hline 1 & $1-5$ & 40 & 53,33 \\
\hline 2 & $6-10$ & 28 & 37,33 \\
\hline 3 & $11-15$ & 4 & 5,33 \\
\hline 4 & $16-20$ & 3 & 4,00 \\
\hline \multicolumn{2}{|r|}{} & 75 & $100 \%$ \\
\hline
\end{tabular}

Sumber: Data Primer Diolah 
Penggunaan modal awal sejumlah antara 1-5 juta rupiah adalah yang paling banyak digunakan ketika memulai usaha tenun lurik yaitu dengan jumlah 40 unit usaha $(53,33 \%)$. Penggunaan modal awal sejumlah antara 15-20 juta rupiah adalah yang paling sedikit digunakan yaitu hanya 3 unit usaha (4\%).

Dalam proses produksi tenun lurik ada dua bahan baku yang digunakan, yaitu benang dan pewarna. Untuk bahan baku benang yang biasa digunakan adalah benang jenis katun dan polyester dan untuk bahan baku pewarna yang biasa digunakan adalah pewarna sintetis. Bahan baku tersebut dapat diperoleh di pasar lokal maupun didatangkan dari daerah lain. Jumlah penggunaan bahan baku dalam proses produksi akan menentukan banyaknya output yang dihasilkan. Berikut adalah tabel penggunaan bahan baku dalam produksi tenun lurik yang dirinci berdasarkan harga bahan baku yang digunakan dalam satu bulan produksi:

Tabel 8

Harga Total Penggunaan Bahan Baku Dalam Satu Bulan Produksi

\begin{tabular}{|c|c|c|c|}
\hline No. & Jumlah Bahan Baku (Juta Rupiah) & Frekuensi & Persentase $(\%)$ \\
\hline 1 & $\leq 5$ & 30 & 40,00 \\
\hline 2 & $5,1-10$ & 34 & 45,33 \\
\hline 3 & $10,1-15$ & 6 & 8,00 \\
\hline 4 & $15,1-20$ & 2 & 2,67 \\
\hline 5 & $>20$ & 3 & 4,00 \\
\hline \multicolumn{2}{|r|}{ Jumlah } & 75 & $100 \%$ \\
\hline
\end{tabular}

Sumber: Data Primer Diolah

Penggunaan bahan baku sebesar 5,110 juta rupiah adalah yang paling banyak diggunakan pada proses produksi tenun lurik dalam satu bulan dengan persentase $45,33 \%$, sedangkan yang paling sedikit digunakan adalah penggunaan bahan baku sebesar 15,1-20 juta rupiah dengan persentase $2,67 \%$.

Dalam melakukan pemasaran produk, rata-rata hasil produksi tenun lurik dipasarkan di daerah sekitar Klaten seperti Yogyakarta, Solo, sampai ke daerahdaerah lain di Pulau Jawa seperti Semarang, Pekalongan, Surabaya, hingga Jakarta. Bahkan ada juga pelaku usaha yang sudah memasarkan produknya sampai ke Bali, Kalimantan, dan Sulawesi. Untuk daerah lokal, pemasaran hasil produksi hanya dilakukan dalam jumlah yang kecil. Dari hasil observasi di lapangan hanya ditemukan satu pelaku usaha yang memasarkan produknya sampai ke pasar luar negeri, tepatnya Australia. Sangat sedikitnya pelaku usaha yang memasarkan produknya sampai ke pasar luar negeri disebabkan karena kurangnya informasi yang dimiliki untuk melakukan proses ekspor produk ke luar negeri. Selain itu proses mendapatkan izin ekspor pun juga sulit untuk didapatkan, sehingga dalam melakukan ekspor produk ke luar negeri pelaku usaha harus menggunakan jasa broker atau perantara yang memiliki akses untuk melakukan kegiatan ekspor. Hal ini tentu menyusahkan pelaku usaha yang akan menjual produknya ke luar negeri karena 
harus mengeluarkan biaya tambahan untuk menggunakan jasa broker sebagai perantara pengiriman produk ke luar negeri.

\section{Analisis Hasil Regresi}

Penelitian ini bertujuan untuk menganalisis faktor-faktor yang mempengaruhi produksi tenun lurik di Kecamatan Cawas. Fungsi produksi yang digunakan dalam analisis adalah fungsi Cobb-Douglas. Pengolahan data dilakukan dengan program eviews 6.0 dengan metode OLS. Model yang diestimasi adalah sebagai berikut:

$$
\begin{gathered}
\log \mathrm{Y}=\log \beta_{0}+\beta_{1} \log \mathrm{X}_{1}+\beta_{2} \log \mathrm{X}_{2}+\beta_{3} \\
\log \mathrm{X}_{3}+\beta_{4} \log \mathrm{X}_{4}+\mu \\
\mathrm{Y}=\text { Output tenun lurik (meter) } \\
\mathrm{X} 3=\text { Bahan baku (rupiah) } \\
\mathrm{X} 1=\text { Tenaga kerja (orang) } \\
\mathrm{X} 4=\text { Modal awal (rupiah) } \\
\mathrm{X} 2=\text { Pengalaman (tahun) }
\end{gathered}
$$

Dari estimasi didapat hasil sebagai berikut:

Tabel 9

Estimasi Faktor-Faktor yang Mempengaruhi Produksi Tenun Lurik

\begin{tabular}{|l|c|c|c|}
\hline \multicolumn{1}{|c|}{ Variabel } & Koefisien & t-Statistik & Probabilitas \\
\hline C (konstanta) & $-5,881834$ & $-4,637780$ & 0,0000 \\
\hline X1 (tenaga kerja) & 0,336508 & 3,516248 & 0,0008 \\
\hline X2 (pengalaman) & 0,077209 & 0,793840 & 0,4300 \\
\hline X3 (bahan baku) & 0,669791 & 7,004759 & 0,0000 \\
\hline X4 (modal awal) & 0,061193 & 1,090229 & 0,2794 \\
\hline $\mathrm{R}^{2}$ & 0,838404 & - & - \\
\hline $\mathrm{F}$ & 90,79483 & - & 0,000000 \\
\hline
\end{tabular}

Sumber: Data Primer Diolah

Berdasarkan hasil estimasi di atas dari empat variabel independen yang mempengaruhi produksi tenun lurik terdapat dua variabel signifikan dan dua variabel tidak signifikan jika dilihat dari nilai probabilitas. Variabel signifikan diantaranya X1 (tenaga kerja), X3 (bahan baku) dimana probabilitasnya berada di bawah nilai $\alpha=10 \%$. Terdapat dua variabel tidak signifikan yaitu X2 (pengalaman), X4 (modal awal) karena nilai probabilitasnya di atas nilai $\alpha=10 \%$.

Hasil estimasi di atas dapat dituliskan menjadi sebuah persamaan sebagai berikut:

$$
\begin{gathered}
\mathrm{Y}=-5,881834 \\
\mathrm{X} 1^{0,336508} \mathrm{X} 2^{0,077209} \mathrm{X} 3^{0,669791} \mathrm{X} 4^{0,061193}
\end{gathered}
$$

Dari persamaan di atas dapat dilihat elastisitas dari tenaga kerja, pengalaman, bahan baku, modal awal dari nilai koefisien hasil regresi. Nilai koefisien dari persamaan tersebut dapat diartikan sebagai berikut:

- Nilai koefisien elastisitas tenaga kerja sebesar 0,336508 menunjukkan setiap penambahan $1 \%$ tenaga kerja dalam produksi akan meningkatkan output sebesar $0,336 \%$.

- Nilai koefisien elastisitas pengalaman sebesar 0,077209 menunjukkan setiap penambahan $1 \%$ pengalaman dalam produksi akan meningkatkan output sebesar $0,077 \%$.

- Nilai koefisien elastisitas bahan baku sebesar 0,669791 menunjukkan setiap 
penambahan $1 \%$ bahan baku dalam produksi akan meningkatkan output sebesar $0,669 \%$.

- Nilai koefisien elastisitas modal awal sebesar 0,061193 menunjukkan setiap penambahan $1 \%$ modal awal dalam produksi akan meningkatkan output sebesar $0,061 \%$.

\section{Pengaruh tenaga kerja terhadap produksi tenun lurik}

Hasil estimasi diperoleh $\mathrm{t}$ hitung untuk variabel tenaga kerja (X1) sebesar 3,516248. Untuk melakukan uji t maka dicari nilai $\mathrm{t}$ kritis dari tabel distribusi $\mathrm{t}$ dengan $\alpha=10 \%$ dan Df (n-k) sebesar 70 maka didapatkan nilai 1,66691. Dengan demikian dapat ditarik kesimpulan bahwa nilai $\mathrm{t}$ hitung $>\mathrm{t}$ tabel. Hal tersebut berarti H0 ditolak, hubungan variabel independen tenaga kerja (X1) dengan variabel dependen (Y) adalah signifikan. Hasil ini sesuai dengan penelitian terdahulu oleh Efie Eka Wanty tahun 2006 bahwa tenaga kerja memiliki pengaruh dalam nilai produksi pada ukm batik di Pekalongan. Sehingga hasil penelitian antara ukm batik di Pekalongan dengan ukm tenun lurik di Kecamatan Cawas adalah sama yaitu variabel tenaga kerja yang yang digunakan memiliki pengaruh terhadap nilai produksi.

\section{Pengaruh pengalaman terhadap produksi tenun lurik}

Hasil estimasi diperoleh $\mathrm{t}$ hitung untuk variabel pengalaman (X2) sebesar 0,793840 . Hasil dari evaluasi adalah nilai $t$ hitung < t kritis $(1,66691)$. Hal tersebut berarti gagal menolak $\mathrm{H} 0$, yang berarti pengaruh variabel pengalaman (X2) terhadap produksi tenun lurik (Y) secara statistik tidak signifikan. Pengalaman dalam usaha tenun lurik tidak berpengaruh karena meski sudah lama menggeluti bidang usaha tenun lurik, namun para pelaku usaha baik dari pengusaha maupun tenaga kerja sebagian besar tidak menjadikan usaha tenun lurik sebagai sumber penghasilan yang utama. Sebagian besar masyarakat di Kecamatan Cawas masih mengandalkan sektor pertanian sebagai sumber penghasilan utama sehingga sering ada anggapan bahwa usaha tenun lurik hanya sekedar usaha sampingan sementara menunggu musim bertani.

\section{Pengaruh bahan baku terhadap produksi tenun lurik}

Hasil estimasi diperoleh $\mathrm{t}$ hitung untuk variabel bahan baku (X3) sebesar 7,004759 . Hasil dari evaluasi adalah nilai $t$ hitung > $\mathrm{t}$ kritis $(1,66691)$. Maka dapat disimpulkan, bahan baku (X3) signifikan terhadap produksi tenun lurik. Produksi tenun lurik sangat ditentukan oleh jumlah bahan baku yang digunakan. Variabel bahan baku memiliki pengaruh positif dalam produksi tenun lurik karena semakin besar jumlah bahan baku yang digunakan maka output tenun lurik yang dihasilkan akan semakin besar pula.

\section{Pengaruh modal awal terhadap produksi tenun lurik}

Hasil estimasi diperoleh $\mathrm{t}$ hitung untuk variabel modal awal (X4) sebesar 1,090229. Hasil dari evaluasi adalah nilai $\mathrm{t}$ hitung $<\mathrm{t}$ kritis $(1,66691)$. Maka dapat disimpulkan, modal awal (X4) tidak signifikan terhadap produksi tenun lurik. Modal awal dalam usaha tenun lurik tidak berpengaruh karena usaha tenun lurik di Kecamatan Cawas sebagian besar berasal dari usaha kecil atau rumah tangga yang ketika memulai usaha tenun lurik tidak harus menggunakan sejumlah uang modal awal dalam jumlah yang besar. Meski 
dengan modal awal yang tidak besar, usaha tenun lurik dapat terus berkembang dengan memanfaatkan keuntungan yang diperoleh untuk kemudian digunakan sebagai modal tambahan untuk membeli peralatan baru serta menambah jumlah bahan baku yang digunakan. Pola manajemen yang masih sederhana menyebabkan banyak usaha tenun lurik tidak dikembangkan secara maksimal, karena tidak semua pelaku usaha yang menjadikan usaha tenun lurik sebagai sumber penghasilan yang utama. Hal tersebut menyebabkan dalam kelanjutan usaha, tidak semua usaha tenun lurik mampu berkembang secara maksimal.

\section{Returns to Scale}

Returns to scale digunakan untuk mengetahui apakah kegiatan produksi dari suatu usaha yang diteliti tersebut berada dalam kondisi increasing, constant, atau decreasing returns to scale. Berdasarkan fungsi Cobb-Douglas, maka dapat diketahui returns to scale pada usaha tenun lurik di Kecamatan Cawas adalah sebagai berikut:

$$
\begin{array}{rl}
\sum \beta_{\mathrm{i}} \quad= & \beta_{1}+\beta 2+\beta_{3}+\beta_{4} \\
& =0,336508+0,077209+0,669791 \\
+0,061 & 193 \\
& =1.144701 \\
& \text { Berdasarkan hasil perhitungan }
\end{array}
$$
returns to scale di atas pada usaha kecil dan menengah tenun lurik di Kecamatan Cawas diperoleh hasil sebesar 1,144701. Hasil tersebut menunjukkan bahwa angka returns to scale lebih dari 1 yang berarti berada pada kondisi increasing returns to scale. Nilai increasing returns to scale sebesar 1,144701 berarti apabila terjadi kenaikan input sebesar 1 persen maka akan menaikkan output produksi sebesar 1,144701 persen. Hasil ini menunjukkan bahwa usaha kecil dan menengah tenun lurik di daerah penelitian ini layak untuk dikembangkan dan dilanjutkan.

\section{KESIMPULAN DAN IMPLIKASI}

Kesimpulan dari penelitian ini adalah sebagai berikut : Dari hasil koefisien determinasi maka variabelvariabel dependen tenaga kerja, pengalaman, bahan baku, dan modal awal dapat menjelaskan pengaruhnya pada produksi tenun lurik sebesar 83,8\%. Variabel tenaga kerja, pengalaman, bahan baku, dan modal awal dalam penelitian ini bersama-sama dapat menjelaskan pengaruh terhadap produksi tenun lurik dalam uji F. Variabel tenaga kerja dan bahan baku berpengaruh positif dan signifikan terhadap produksi tenun lurik. Variabel pengalaman dan modal awal berpengaruh positif dan tidak signifikan terhadap produksi tenun lurik. Hasil produksi tenun lurik dalam kondisi increasing return to scale. Hal ini ditunjukkan dari nilai 1,144701 > 1 yang berarti apabila terjadi kenaikan input sebesar 1 persen maka akan menaikkan output produksi sebesar 1,144701 persen.

Implikasi dari hasil penelitian ini perlu adanya proses pelatihan dan perekrutan tenaga kerja baru untuk menenun lurik karena tenaga kerja akan mempengaruhi hasil produksi tenun lurik. Perlu adanya terobosan dalam melakukan pemasaran hasil produksi tenun lurik. Antara lain dengan memanfaatkan teknologi informasi dalam memasarkan produk dengan memanfaatkan media internet sebagai sarana melakukan promosi dan pemasaran produk. Pemerintah diharapkan mampu membantu perkembangan usaha kecil dan menengah tenun lurik dengan memberikan pelatihan dan pembinaan terhadap tenaga kerja untuk menenun lurik, serta memberikan 
suntikan modal sehingga usaha tenun lurik mampu terus berkembang.

\section{DAFTAR PUSTAKA}

Arifin, N. (2010). Tenun Tradisional di Tengah Persaingan Era Pasar Bebas. Yogyakarta: UIN Sunan Kalijaga.

Hariyanto, I. (2012). Tenun Lurik Dalam Kehidupan Masyarakat Jawa. Jurnal Kriya Seni ISI Surakarta , 107122.

Hidayat, A. (2013). Analisis Efisiensi Penggunaan Faktor-Faktor Produksi Pada Usaha Kecil dan Menengah Batik di Kelurahan Kauman Kota Pekalongan. Semarang: Universitas Negeri Semarang.

Lestariningsih, S. (2006). Analisis Penawaran dan Permintaan Industri Kecil Tenun Ikat Troso di Kecamatan Pecangaan Kabupaten Jepara. Semarang: Universitas Diponegoro.

Pindyck, R. S. (2009). Mikroekonomi. Jakarta: Indeks.

Reksohadiprodjo, S. (1999). Manajemen Produksi. Yogyakarta: BPFE.

Salvatore, D. (2011). Ekonomi Internasional. Jakarta: Erlangga.

Simanjuntak, P. J. (1999). Pengantar Ekonomi Sumber Daya Manusia. Jakarta: Fakultas Ekonomi Universitas Indonesia.

Soekartawi. (2003). Teori Ekonomi Produksi Dengan Pokok Bahasan Analisis Fungsi Cobb- Douglas. Jakarta: Raja Grafindo Persada.

Sukirno, S. (2003). Pengantar Teori Ekonomi. Jakarta: Raja Grafindo Persada. Sulam, A. L. (2008). Teknik Pembuatan Benang dan Pembuatan Kain.
Jakarta: Direktorat Pembinaan

Sekolah Menengah Kejuruan.

Sulistyastuti, D. R. (2004). Dinamika

UKM, Analisis Konsentrasi

Regional UKM di Indonesia 1999-2001. Jurnal Ekonomi Pembangunan, 143-164.

Suryadi, P. (2009). In Statistik untuk Ekonomi dan Keuangan Modern. Jakarta: Salemba Empat.

Syukur. (2001). Metode Penelitian dan Penyajian Data Pendidikan. Semarang: Medya Wiyata.

Wanty, E. E. (2006). Analisis Produksi Batik Cap Dari UKM Batik Kota Pekalongan. Semarang: Universitas Diponegoro.

Wardani, N. D. (2011). Kain Lurik Pedan Dan Upaya Pelestarian. Semarang: Universitas Negeri Semarang.

Widarjono, A. (2013). Ekonometrika Pengantar dan Aplikasinya. Yogyakarta: UPP STIM YKPN.

Widodo, S. T. (2008). Produksi Tenun ATBM Dengan Aplikasi Dan Variasi Pakan Non Benang. Jurnal Seni Rupa Dan Desain , 24-35.

Yuafni. (2012). Faktor-Faktor yang Mempengaruhi Produksi Batik Pada Industri Batik Jambi di Kota Jambi. Padang: Universitas Negeri Padang. 